\title{
Pembayaran Pajak Penghasilan Terkait Keotentikan Perjanjian Pengikatan Jual Beli
}

\author{
Anak Agung Gde Angga Kusuma Putra ${ }^{1}$ \\ ${ }^{1}$ Program Studi Magister (S2) Kenotariatan Fakultas Hukum Universitas Udayana, E-mail: \\ agungdeangga73@gmail.com
}

\begin{tabular}{l}
\hline Info Artikel \\
\hline Masuk : 2 Juli 2019 \\
Diterima : 1 Agustus 2019 \\
Terbit : 30 Desember 2019 \\
Keywords : \\
Income Tax; Authentic \\
Certificate; Legally Binding \\
Purchase Certificate \\
\\
\\
Kata kunci: \\
Pajak Penghasilan; Akta \\
Otentik; Akta Perjanjian \\
Pengikatan Jual Beli \\
Corresponding Author: \\
Anak Agung Gde Angga \\
Kusuma Puta, \\
E-mail: \\
agungdeangga73@gmail.com \\
DOI : \\
10.24843/AC.2019.v04.i03.p09 \\
\end{tabular}

\begin{abstract}
Article 1 paragraph (1) of Government Regulation Number 34 Year 2016 states that a person or entity that obtains income from the transfer of rights to land and/or buildings is subject to final income tax. Regarding the PPh payment period stipulated in Article 3 paragraph (1) PP No. 34 of 2016 stipulates that PPh is paid before the deed is signed. The two provisions of this rule there has been a contradiction, namely when the PPh payment is paid. PPh paid before the deed is signed will affect the authenticity of the PPJB deed made by the Notary. The PPJB deed is an authentic deed which is given the appropriate number and date when the PPJB deed is signed. This study aims to provide legal certainty about the authenticity of the PPJB deed related to the payment of income tax. Normative legal research is a type of research that is used in this study. The result of this research shows that PPh should be paid after the PPJB was signed in acxordanxe to the provision under Article 1 point (1). Whenever the PPh is paid prior to the signing, it may cause legal misunderstanding and justice to both parties especially the seller, as well as causing inauthenticity of the PPJB made by the Notary.
\end{abstract}


pihak penjual, serta dapat mengakibatkan ketidakotentikan akta PPJB yang dibuat oleh Notaris.

\section{Pendahuluan}

Seiring berjalannya waktu, penggunaan tanah dan/atau bangunan terus meningkat guna menunjang pembangunan yang terus berkembang. Dengan berkembangnya pembangunan-pembangunan saat ini, kebutuhan terhadap tanah maupun bangunan semakin banyak terjadi dikalangan perbisnisan. Bisnis tersebut biasanya dilakukan dengan perjanjian-perjanjian secara legal. Perjanjian-perjanjian tersebut dibuatkan berupa Akta Perjanjian Pengikatan Jual Beli (selanjutnya disebut akta PPJB).

Bisnis property berupa perjanjian antara pihak penjual dan pihak pembeli terjadi apabila telah terjadi kesepakatan dan penyesuaian kehendak antara kedua belah pihak terkait dengan tanah dan/atau bangunan beserta harganya. Pasal 1458 Kitab UndangUndang Hukum Perdata (selanjutnya disebut KUH Perdata) yang pada intinya "untuk terjadinya jual beli maka pihak yang terlibat dalam proses tersebut diharuskan untuk mencapai kata sepakat agar obyek yang dijual dan harganya telah mencapai kesepakatan sesuai dengan kehendak pihak yang terlibat."

Pada proses jual beli harus memperhatikan bentuk-bentuk yang harus dipenuhi, berupa baik dari segi objek maupun subjeknya. Selain itu, harus diperhatikan juga bahwa tanah dan/atau bangunan yang diperjualbelikan tidak dalam sengketa dengan pihak lainnya atau sitaan karena suatu hal tertentu, maupun sebagai jaminan kredit suatu bank. Sedangkan dari segi subjek, yang harus diperhatikan yaitu adanya pihak penjual dan pihak pembeli.

Proses selanjutnya untuk mengalihkan hak atas tanah dan/atau bangunan terdahulu menjadi pemilik yang baru, maka tahap pertama adalah dengan dibuatkannya akta PPJB. Akta PPJB merupakan suatu implementasi dari asas kebebasan berkontrak, dimana penjual dan pembeli dapat mengutarakan maksud dan tujuannya kepada Notaris, yang akan menjadi undang-undangnya sendiri yang akan dituangkan dalam perjanjian tersebut dan mengikat kedua belah pihak. ${ }^{1}$ Pengikatan tersebut dapat dilakukan apabila para pihak telah sekapat atau hanya sebatas tanda jadi untuk tanah dan/atau bangunan yang akan dibeli. Dengan dibuatkan akta PPJB maka para pihak telah dianggap sah untuk menjual tanah yang telah diperjanjikan. Setelah tahap PPJB dilakukan, maka selanjutnya adalah pembuatan Akta Jual Beli (selanjutnya disebut AJB) yang dibuat di hadapan PPAT. Perbedaan antara akta PPJB dan AJB langsung yaitu dibedakan dalam kewenangannya, dimana PPJB dilakukan oleh Notaris sedangkan AJB dilakukan di hadapan PPAT. Hal tersebut dikarenakan PPAT memiliki tugas untuk membantu peralihan hak tanah yang lama ke pemilik tanah yang baru. Perbedaan latar belakang dari kedua akta di atas, akta-akta itu tetap bersifat mengikat untuk penjual dan pembeli, kedua ahli waris masing-masing, serta para penerima hak

\footnotetext{
${ }^{1}$ Rysti Hening Hendrastiti, Widodo Suryandono. (2019). Implikasi Hukum Terhadap Perjanjian Pengikatan Jual Beli Dan Akta Kuasa Jual Yang Dibuat Secara Melawan Hukum (Studi Kasus Putusan Pengadilan Negeri Gianyar Nomor 10/PDT.G/2018/PN.GIN). Indonesian Notary Vol. 1 No. 002. hal. 2.
} 
yang meninggal dunia, baik dari segi harganya yang dibayarkan secara lunas atau mencicil. ${ }^{2}$

Segala proses diatas, baik PPJB dan pembuatan AJB memiliki persamaan dalam penerapan hukumnya. Hal tersebut sama-sama diatur dalam KUH Perdata yang pada intinya membahas mengenai kesepakatan yang telah disepakati, memiliki kecakapan dalam perbuatan hukum, memiliki itikad baik dalam melaksanakan perbuatan hukum dan tidak melanggar ketentuan undang-undang sesuai dengan Pasal 1320 KUH Perdata. Penegasan terhadap keotentikan akta juga diatur dalam ketentuan Pasal 1868 KUH Perdata pada pokoknya mengkaji tentang akta yang dianggap otentik jika akta tersebut telah dibuat oleh pejabat yang memang berwenang membuatnya. Dalam konteks akta PPJB, akta tersebut memiliki dasar yang kuat terhadap Pasal 1320 KUH Perdata namun akta PPJB memiliki ciri khusus yang berbeda seperti:

1. Akta yang belum lunas, biasanya dibuatkan ketika perjanjian tersebut masih ada kendala dalam kesepakatannya. Kesepakatannya dalam hal pembayaran yang tidak dibayarkan secara langsung atau pembayaran tersebut belum lunas.

2. Akta yang telah terbayarkan lunas, biasanya akta ini dibuat berdasarkan ketika perjanjian tersebut benar-benar telah disepakati. Hal tersebut dikarenakan kesepakatan yang diwajibkan telah dipenuhi dan sudah disiapkan untuk dibuatkan AJB.

Berdasarkan ciri khusus itu, tidak memberikan pembedaan dalam kekuatan hukum dari perjanjian tersebut. Meskipun akta tersebut belum lunas ataupun sudah terbayarkan tidak akan mengubah status kepastian dalam kekuatan pembuktian dan pengikatan dalam PPJB tersebut. Jadi, untuk kekuatan hukumnya tidak pernah diragukan meskipun dalam pembuatan akta tersebut belum lunas.

Suatu bukti yang kuat tidak hanya diberikan oleh akta otentik, tapi memberi pembuktian yang kuat. Pemberian bukti yang utuh, lengkap, teratur, baik sekali, dan selesai, sehingga tidak ada lagi yang dapat dipermasalahkan atasnya. Akta otentik telah menjamin kekuatan kepastian yang tersurat dalam akta tersebut, maka kejadian yang terjadi tidak kurang dan tidak lebih. Kepastian yang dijamin dalam akta otentik adalah pasti mengenai waktunya, pasti mengenai subjek hukumnya, pasti mengenai perbuatan hukumnya, serta pasti mengenai objeknya. ${ }^{3}$ Secara umum fungsi dari akta dibagi menjadi 2 fungsi yaitu fungsi formil dapat ditafsirkan bahwa guna membuat suatu per-buatan dinyatakan lengkap dan segala bentuk perbuatan yang telah terjadi telah sah dianggap sempurna. Alat bukti sebagai fungsinya bisa ditafsirkan menjadi akta otentik dibuat dengan sengaja yang bertujuan sebagai pembuktian dikeesokan hari, akta otentik tersebut tertuang secara tertulis terhadap suatu perjanjian. ${ }^{4}$

Meningkatnya transaksi jual beli hak atas tanah membuat pemerintah menetapkan iuran berupa wajib membayar pajak. Pajak yaitu suatu pembayaran iuran yang diwajibkan oleh negara sesuai dengan aturan yang telah mengatur dan bersifat

\footnotetext{
${ }^{2}$ Leny Kurniawati. (2018). Akta Perjanjian Pengikatan Jual Beli Dan Kuasa Menjual Sebagai Bentuk Perlindungan Hukum Terhadap Pembeli Hak Atas Tanah. Jurnal Hukum Dan Kenotariatan Volume II Nomor 1, Februari 2018. hal. 8.

3I Nyoman Alit Puspadma. (2015). Fungsi Dan Wewenang Notaris Dalam Pembuatan Akta. Jurnal Hukum Persada No. 1 Vol. 3 September 2015. hal. 137.

${ }^{4}$ Agus Toni Purnayasa. (2018). Akibat Hukum Terdegradasinya Akta Notaris Yang Tidak Memenuhi Syarat Pembuatan Akta Autentik. Acta Comitas. hal. 397.
} 
memaksa untuk membayar uang kepada Negara. ${ }^{5}$ Peraturan tentang pajak penghasilan telah dirumuskan dalam UU Nomor 7 Tahun 1983 tentang Pajak Penghasilan, sebagaimana telah beberapa kali mengalami perubahan dan terakhir kali di ubah dengan Undang-Undang Nomor 36 Tahun 2008 tentang Perubahan Keempat atas Undang-Undang Nomor 7 Tahun 1983 tentang Pajak Penghasilan (selanjutnya disebut UU PPh). Pajak yang bersifat final diatur dalam ketentuan Pasal 4 ayat (2) huruf d UU PPh, kemudian diatur melalui Peraturan Pemerintah (selanjutnya disebut PP). PP tersebut adalah PP Nomor 48 Tahun 1994 tentang Pembayaran Pajak Penghasilan Atas Penghasilan Dari Pengalihan Hak Atas Tanah Dan/Atau Bangunan, yang telah beberapa kali mengalami perubahan dan perubahan terakhir dengan PP Nomor 34 Tahun 2016 tentang Pajak Penghasilan Atas Penghasilan Dari Pengalihan Hak Atas Tanah dan/atau Bangunan, Dan Perjanjian Pengikatan Jual Beli Atas Tanah dan/atau Bangunan Beserta Perubahannya.

Dalam kaitannya dengan keotentikan suatu akta dengan PP Nomor 34 Tahun 2016 ini dapat diperhatikan dalam rumusan Pasal 3 ayat (1), yang pada intinya menerangkan bahwa PPh harus dibayar terlebih dahulu sebelum penandatanganan akta di hadapan pejabat yang berwenang. Jika dicermati berarti pihak penjual wajib membayar PPhnya sebelum akta ditandatangani, akan tetapi dalam transaksi jual beli penghasilan baru diperoleh penjual saat setelah penandatanganan akta PPJB.

Mengacu pada ketentuan Pasal 1 ayat (1) menentukan bahwa PPh dikenakan terhadap penghasilan yang diperoleh, bukan terhadap penghasilan yang akan diterima. Penghasilan baru diterima saat setelah penandatanganan akta PPJB di hadapan Notaris, selanjutnya akta PPJB tersebut diberi nomor dan tanggal yang sesuai pada tanggal akta PPJB ditandatangani sehingga akta PPJB menjadi otentik. Hal itulah yang seharusnya PPh dibayarkan setelah kedua pihak bersama-sama menandatangani akta PPJB di hadapan Notaris, bukan saat sebelum akta PPJB ditandatangani yang menimbulkan ketidakpastian hukum dan ketidakadilan bagi pihak penjual.

Berdasarkan penjelasan yang sudah diterangkan di atas, timbul permasalahan yang menjadi pembahasan penelitian ini meliputi:

1. Bagaimana keotentikan akta PPJB yang dibuat oleh Notaris dalam proses transaksi jual beli hak atas tanah dan/atau bangunan?

2. Bagaimana kedudukan pembayaran PPh terkait dengan keotentikan akta PPJB yang dibuat oleh Notaris?

Tujuan penelitian ini secara garis besar yaitu untuk memahami keotentikan akta PPJB dalam proses transaksi jual beli hak atas tanah dan/atau bangunan, memberi pemahaman dan penjelasan terkait dengan kedudukan pembayaran $\mathrm{PPh}$ terkait dengan keotentikan akta PPJB, dan memberi kepastian hukum serta keadilan bagi pihak-pihak supaya dikemudian hari tidak terjadi kesenjangan dari peraturanperaturan yang mengatur hal-hal tersebut.

\section{Metode Penelitian}

Penggunaan metode dalam studi penelitian ini yaitu secara hukum normatif, dikarenakan adanya kesenjangan norma antara PP Nomor 34 Tahun 2016 mengenai

${ }^{5}$ H. Bohari. (2012). Pengantar Hukum Pajak. Jakarta: PT. Raja Grafindo Persada. hal. 23. 
pembayaran PPh dengan keotentikan akta PPJB yang diatur dalam KUH Perdata dan UUJNP. Metode pendekatan perundang-undangan dan pendekatan konseptual merupakan 2 (dua) metode pendekatan pada penelitian ini. Penggunaan bahan hukum primer dan sekunder berhubungan dengan suatu kaidah dasar dan peraturan yang mempunyai korelasi dengan kedua permasalahan di atas. Bahan hukum yang dikumpulkan yang dipakai disini dengan cara penelitian kepustakaan. Penelitian kepustaakaan yang dimaksud berhubungan terhadap pembayaran PPh yang berkaitan dengan keotentikan akta PPJB Notaris.

\section{Hasil dan Pembahasan}

\subsection{Keotentikan Akta PPJB Yang Dibuat Oleh Notaris Dalam Proses Transaksi Jual Beli Hak Atas Tanah Dan/Atau Bangunan}

Dalam pengertian secara umum, Notaris adalah seorang pejabat yang diberikan kewenangan untuk menuangkan segala bentuk perjanjian ataupun perbuatanperbuatan hukum secara perdata yang sudah diatur dan dilindungi oleh undangundang. Ketentuan tersebut merupakan intisari dari pemahaman Pasal 1 angka 1 Undang-Undang Nomor 2 Tahun 2014 tentang Perubahan Atas Undang-Undang Nomor 30 Tahun 2004 tentang Jabatan Notaris (selanjutnya disebut UUJNP) yang secara tegas menyatakan bahwa Notaris ditugaskan sebagai pejabat yang memang berwenang dalam membantu negara dalam melaksanakan tugas sebagai pengatur hubungan hukum antara orang perorangan maupun badan hukum secara perdata.

Selain tugas diatas, ada beberapa wewenang Notaris yang telah diatur juga dalam UUJNP. Kewenangan tersebut masih di dalam konteks perbuatan hukum perdata dari orang perorangan, baik dalam hal pembuatan suatu akta para pihak yang telah datang dan menghadap Notaris akan memberikan keinginannya untuk melangsungkan perbuatan hukum baik itu berupa poin-poin penting yang akan dituangkan kedalam akta maupun hal-hal yang diwajibkan Notaris untuk menjalankan prosedur pelaksanaan pembuatan akta. Setelah prosedur pembuatan akta diselesaikan, Notaris akan menjamin segala hal yang berhubungan dengan akta tersebut, contohnya tanggal yang telah terjamin, akta yang akan disimpan, memberikan grose dan salinan beserta hal-hal yang diwajibkan oleh UUJNP yang diatur dalam ketentuan Pasal 15.

Segala kewenangan diatas, segala bentuk kemauan dari penghadap merupakan bagian dari pengaturan di dalam UUJNP dikarenakan dalam pembuatan akta harus didasarkan oleh keinginan para pihak, serta memberikan pertimbangan hukum ketika segala bentuk keinginan para pihak telah di sampaikan, yang pada akhirnya para pihak tidak ada yang berasumsi dirugikan ketika perjanjian tersebut telah berlaku. Dengan diselesaikannya tahap pembuatan akta perjanjian tersebut, Notaris ditugaskan oleh undang-undang untuk membacakan segala isi yang tertuang dari akta serta para pihak harus mendengarkan isi yang dibacakan oleh Notaris agar para pihak paham isi dari akta tersebut. Apabila akta telah dibacakan, maka selanjutnya para pihak diwajibkan untuk menandatangani akta tersebut. ${ }^{6}$ Dengan dibacakan, ditandatangani dan disaksikan oleh para saksi maka akta tersebut telah dinyatakan otentik.

${ }^{6}$ I Ketut Tjukup. (2016). Akta Notaris (Akta Otentik) Sebagai Alat Bukti Dalam Peristiwa Hukum Perdata. Acta Comitas. hal. 182. 
Keotentikan akta PPJB berdasarkan KUH Perdata, pertama dari bentuk aktanya sudah harus memiliki kesesuaian terhadap bentuk yang ditetapkan oleh undang-undang, selanjutnya ditandatangani di hadapan Notaris, dan diberi tanggal serta dinomorkan. Nomor dan tanggal yang dibuat harus sama yang tercantum dalam akta PPJB, merupakan tanggal saat perbuatan hukum itu dilakukan, bukan sehari sebelumnya atau sehari setelahnya. Selain daripada itu, keotentikan suatu akta PPJB juga harus memenuhi persyaratan terbentuknya suatu akta oleh Notaris dalam Pasal 38 UUJNP.

Pihak-pihak yang hendak bertransaksi datang ke kantor Notaris guna menyampaikan keterangan dan/atau pernyataannya untuk dibuatkan akta PPJB. Pada hari yang telah ditentukan, para pihak hadir kembali ke kantor Notaris untuk menandatangani akta PPJB yang sudah dibuat oleh Notaris. Selesai menandatangani akta PPJB, maka demi kepastian hukum Notaris memberikan nomor dan tanggal hari itu juga, yang artinya apabila akta PPJB ditandatangani pada hari Jumat tanggal 21 Juni 2019, maka pada akta PPJB harus ditulis pula tanggal tersebut, bukan tanggal seminggu atau beberapa hari sebelumnya, atau seminggu atau beberapa hari setelahnya. Hal tersebut dilakukan karena pihak-pihak yang melakukan perbuatan hukum dibuktikan dengan saat penandatanganan akta, sehingga keotentikan akta PPJB tentang saat dilakukannya perbuatan hukum dapat dijamin kebenarannya. Apabila akta PPJB diberi nomor dan tanggal yang berbeda maka akan menyebabkan ketidakotentikan akta PPJB itu sendiri sehingga dapat batal demi hukum.

Keotentikan akta PPJB memberikan kepastian, bahwa apa yang tersurat dalam akta PPJB tersebut demikianlah kejadian yang terjadi tidak kurang dan tidak lebih. Kepastian yang dijamin dalam keotentikan akta PPJB yaitu pasti mengenai waktunya, pasti mengenai subjek hukumnya, pasti mengenai perbuatan hukumnya, serta pasti mengenai objeknya. Artinya, benar pada tanggal yang tertera di akta merupakan saat tindakan hukum dilakukan, bukan tanggal lain. Benar subjek hukum yang hadir pada tanggal itu adalah subjek hukum yang tertulis pada akta, bukan subjek hukum lain. Benar pada tanggal tersebut subjek hukum yang tercantum dalam akta tersebut, telah melakukan suatu perbuatan hukum yang tertera dalam akta tersebut, bukan perbuatan hukum lain. Benar benda atau hal sebagai objek transaksi jual beli pada tanggal tersebut yang dilakukan subjek hukum tersebut adalah benda atau hal yang tertera pada akta tersebut, bukan benda atau hal yang lain. ${ }^{7}$

\subsection{Kedudukan Pembayaran PPh Terkait Dengan Keotentikan Akta PPJB Yang Dibuat Oleh Notaris}

Pembahasan mengenai pembayaran PPh, terlebih dahulu harus memperhatikan ketentuan dari Pasal 1 ayat (1) PP Nomor 34 Tahun 2016, pada intinya menjabarkan bahwa segala perbuatan hukum yang dilakukan orang secara pribadi atau badan hukum atas suatu beralihnya hak atas tanah dan/atau bangunan dan segala bentuk perbuatan hukum secara perdata yang menghasilkan suatu penghasilan terutang PPh final. Menindaklanjuti ketentuan tersebut, maka penghasilan yang terutang PPh final bersumber pada pengalihan atau dari PPJB atas tanah dan/atau bangunan. Oleh karena itu, seseorang atau badan terutang pajak penghasilan adalah saat setelah seseorang atau badan menerima penghasilan, bukan saat sebelum menerima penghasilan.

${ }^{7}$ I Nyoman Alit Puspadma. Op. Cit. hal. 137-138. 
Mengenai waktu pembayaran PPh telah dijelaskan dalam Pasal 3 ayat (1) PP Nomor 34 Tahun 2016, kembali menyimak pada ketentuan dari Pasal 1 ayat (1), dalam pembayaran $\mathrm{PPh}$ sudah terjadi kontradiksi dalam satu (1) peraturan yang sama. Ketentuan Pasal 1 ayat (1) menyatakan seseorang dan juga badan terutang pajak penghasilan pada saat setelah menerima atau memperoleh penghasilan. Penerimaan atau perolehan penghasilan oleh seseorang atau badan tersebut pada saat setelah akta PPJB ditandatangani, namun pada Pasal 3 ayat (1) menyatakan penerimaan atau perolehan penghasilan seseorang atau badan yang diterima atau diperoleh dari jual beli atas tanah dan/atau bangunan berkewajiban membayar PPh-nya sebelum akta ditandatangani. Jika orang atau badan membayar PPh-nya sebelum akta ditandatangani, maka penjual belum memperoleh penghasilannya mengingat ketentuan dalam Pasal 1 ayat (1) diatas.

Jika seseorang maupun badan membayar PPh-nya sebelum akta ditandatangani, maka kepastian hukum bagi seseorang atau badan tersebut tidak terjamin, karena ia membayar terlebih dahulu PPh-nya saat sebelum akta ditandatangani dimana penghasilan atas penjualan tanah dan/atau bangunannya belum ia terima, serta belum adanya perjanjian hitam diatas putih antara ia sebagai penjual dengan pembeli. Selain tidak adanya kepastian hukum dengan pembayaran $\mathrm{PPh}$ sebelum akta ditandatangani, juga menimbulkan ketidakadilan. Ketidakadilan yang ditimbulkan tentu saja bagi penjual yang harus membayar PPh-nya sebelum ia menerima atau memperoleh penghasilannya. Jika proses transaksi jual beli berjalan dengan lancar tentu tidak akan ada masalah dan tidak ada yang dirugikan, tetapi jika kemudian hari setelah PPh dibayarkan kemudian transaksi batal karena sesuatu dan lain hal, disinilah pihak penjual akan sangat dirugikan, karena ia telah membayar PPh tetapi tidak menerima penghasilan. Bagi wajib pajak dari kalangan ekonomi menengah ke bawah tentu saja akan sangat memberatkan dengan peraturan seperti ini karena ia belum tentu memiliki uang dengan jumlah yang cukup untuk membayar PPh-nya terlebih dahulu, sebelum ia menerima uang dari penjualan tanah dan/atau bangunan miliknya.

Menyimak ketentuan Pasal 3 ayat (1), berkaitan dengan keotentikan akta PPJB Notaris harus memperhatikan persyaratan akta otentik itu dibuat oleh Notaris. Keotentikan suatu akta PPJB sebagaimana yang sudah dijelaskan pada pembahasan diatas yaitu akta PPJB yang otentik adalah akta yang saat penandatanganannya dilakukan pihakpihak, saksi-saksi, dan Notaris adalah waktu yang tertera di akta PPJB adalah hari serta tanggal yang sama, bukan yang berlainan. Jika pihak-pihak hadir di hadapan Notaris, pihak pembeli mau membayar harga tanah dan/bangunan yang dijual penjual, selanjutnya para pihak menandatangani akta PPJB, kemudian pihak penjual membayar PPh-nya. Guna mengakali ketentuan Pasal 3 ayat (1), akta yang ditandatangani para pihak sebelumnya tidak diberi nomor dan tanggal yang sesuai pada saat penandatanganan sehingga pembayaran PPh sebelum akta ditandatangani terpenuhi. Setelah PPh dibayar, penjual datang kembali ke kantor Notaris dengan membawa bukti pembayaran PPh-nya, dan akta PPJB yang ditandatangani sebelumnya baru diberi nomor dan tanggal saat penjual membawa bukti pembayar PPh. Hal seperti ini tentu saja tidak boleh karena berakibat akta PPJB menjadi tidak otentik.

Kedudukan pembayaran PPh yang sebenarnya tepat mengacu pada ketentuan Pasal 1 ayat (1), bahwa PPh dikenakan atas penghasilan yang diterima pihak penjual, bukan atas penghasilan yang akan diterimanya. Penghasilan yang diterima oleh pihak 
penjual saat setelah ia dan pembeli menandatangani akta PPJB di hadapan Notaris, bukan sebelum akta PPJB ditandatangani, sehingga pembayaran PPh seharusnya dibayarkan setelah akta PPJB ditandatangani. Akta PPJB yang ditandatangi para pihak pun juga menjadi akta yang otentik karena setalah ditandatangani, pada saat itu juga langsung diberi nomor dan tanggal yang sesuai pada saat penandatanganannya.

\section{Kesimpulan}

Keotentikan akta PPJB dalam transaksi jual beli tanah dan/atau bangunan adalah akta yang otentik apabila akta PPJB tersebut telah ditandatangani oleh para pihak, diberi nomor dan tanggal pada saat akta PPJB ditandatangani saat perbuatan hukum itu dilakukan, bukan tanggal seminggu atau beberapa hari setelahnya, atau tanggal seminggu atau beberapa hari sebelumnya.

Kedudukan pembayaran PPh terkait dengan keotentikan akta PPJB adalah saat penghasilan diterima penjual, sesuai dengan ketentuan Pasal 1 ayat (1). Penghasilan yang diterima yaitu saat setelah penjual dan pembeli menandatangani akta PPJB di hadapan Notaris, bukan sebelum akta PPJB ditandatangani, karena PPh dikenakan atas penghasilan yang diterima, bukan atas penghasilan yang akan diterima. Akta PPJB yang telah ditandatangani kemudian diberi nomor dan tanggal yang sama, sehingga akta PPJB tersebut menjadi otentik serta kepastian hukum dan keadilan terpenuhi.

\section{Daftar Pustaka}

Buku

Bohari, H. (2012). Pengantar Hukum Pajak. Jakarta: PT. Raja Grafindo Persada.

\section{Jurnal}

Hendrastiti, Rysti Hening, Widodo Suryandono. (2019). Implikasi Hukum Terhadap Perjanjian Pengikatan Jual Beli Dan Akta Kuasa Jual Yang Dibuat Secara Melawan Hukum (Studi Kasus Putusan Pengadilan Negeri Gianyar Nomor 10/PDT.G/2018/PN.GIN). Indonesian Notary, Vol. 1, No. 002.

Kurniawati, Leny. (2018). Akta Perjanjian Pengikatan Jual Beli Dan Kuasa Menjual Sebagai Bentuk Perlindungan Hukum Terhadap Pembeli Hak Atas Tanah. Jurnal Hukum Dan Kenotariatan Volume II, Nomor 1, Februari 2018.

Purnayasa, Agus Toni. (2018). Akibat Hukum Terdegradasinya Akta Notaris Yang Tidak Memenuhi Syarat Pembuatan Akta Autentik. Acta Comitas.

Puspadma, I Nyoman Alit. (2015). Fungsi Dan Wewenang Notaris Dalam Pembuatan Akta. Jurnal Hukum Persada No. 1 Vol. 3 September 2015.

Tjukup, I Ketut. (2016). Akta Notaris (Akta Otentik) Sebagai Alat Bukti Dalam Peristiwa Hukum Perdata. Acta Comitas.

\section{Perundang-undangan}

Kitab Undang-Undang Hukum Perdata.

Undang-Undang Nomor 30 Tahun 2004 tentang Jabatan Notaris (Lem-baran Negara Republik Indonesia Tahun 2004 Nomor 117, Tamba-han Lembaran Negara Republik Indonesia Nomor 4432). 
Undang-Undang Nomor 2 Tahun 2014 tentang Perubahan Atas Undang-Undang Nomor 30 Tahun 2004 tentang Jabatan Notaris (Lembaran Negara Republik Indonesia Tahun 2014 Nomor 3, Tambahan Lembaran Negara Republik Indonesia Nomor 5491).

Undang-Undang Nomor 36 Tahun 2008 tentang Perubahan Keempat atas UndangUndang Nomor 7 Tahun 1983 tentang Pajak Penghasilan (Lembaran Negara Republik Indonesia Tahun 2008 Nomor 133, Tambahan Lembaran Negara Republik Indonesia Nomor 4893).

Peraturan Pemerintah Nomor 34 Tahun 2016 tentang Pajak Penghasilan Atas Penghasilan Dari Pengalihan Hak Atas Tanah dan/atau Bangunan, Dan Perjanjian Pengikatan Jual Beli Atas Tanah dan/atau Bangunan Beserta Perubahannya. 